\title{
KONSORSIUM TUMBUHAN ANTI MOLUSKA UNTUK MENGENDALIKAN KEONG MAS HAMA TANAMAN PADI
}

\author{
Baiq Farista, Suripto, Erin Ryantin Gunawan dan Kurniasih Sukenti \\ Program Studi Biologi Fakultas MIPA Universitas Mataram
}

\begin{abstract}
ABSTRAK
Penelitian ini diarahkan untuk mengembangkan pemberdayaan sejumlah jenis tumbuhan anti moluska yang selektif fisiologis dan aplikasinya yang selektif ekologis untuk mengendalikan keong mas hama tanaman padi. Data mortalitas keong mas diolah dengan menggunakan program analisis probit untuk menentukan $\mathrm{LC}_{50}$. Hasil menunjukkan, bahwa preferesi keong mas terhadap tanaman padi tidak dipengaruhi oleh variasi kultivar akan tetapi dipengaruhi oleh umur tanaman padi. Tanaman padi 10 hari dan 20 hari lebih disukai oleh keong mas daripada tanaman padi 60 hari. Keong mas berusia enam bulan mempunyai kecepatan makan tanaman padi dua kali lipat dari keong mas berusia tiga bulan an empat kali lipat dari eong mas berusia satu bulan. Keberadaan keong mas dan aplikasi molusisida di lapangan tidak mempengaruhi keanekaragaman moluska di sawah padi. Sifat anti moluska terhadap keong mas dari $C$. gigantea, $C$. rotundus, $P$. angulata dan $S$. grandiflora ditunjukkan terutama oleh fraksi ekstrak non-polar, dengan $\mathrm{LC}_{50}$ berturut-turut adalah 29,19 ppm, 18,84 ppm, 22,17 ppm dan 546,53 ppp, sedangkan sifat anti muluska dari $S$. sesban terutama ditunjukkan oleh fraksi ekstrak polar, dengan $\mathrm{LC}_{50} 164,55 \mathrm{ppm}$. Golongan senyawa yang terutama aktif anti moluska dari $C$. gigantea, $C$. rotundus, $P$. angulata, $S$. grandiflora dan $S$. sesban berturutturut adalah alkaloid, steroid, asam fenolat, dan saponin.
\end{abstract}

Kata-kata kunci: tumbuhan anti moluska, preferensi dan kecepatan makan keong mas, kultivar dan umur padi, keanekaragaman jenis moluska

\begin{abstract}
This research was conducted for developing a number of physiological selective antimollusk plants species and ecological selective application for controlling of gold snail (keong mas), fest of rice plant. Data of gold snail mortality were analyzed using probit analysis for $\mathrm{LC}_{50}$ determination. The results of this research show, that preferesi of gold snail to rice plant was not influenced by varieties of cultivar, but it was influenced by the age of rice plant. The rice plants of 10 and 20 days old were like more by gold snail compare to the rice plant at the age of 60 days. The feeding speed to rice plant of gold snail of 6 months old was double compare to gold snail of 3 months old, and four time faster than keong mas of 1 month old. The present of gold snail and aplication of molusisida on the field were no effects to the diversity of mollusk in paddy field (sawah). Characteristics of antimollusk to gold snail of C. gigantea, $C$. rotundus, $P$. angulata and $S$. grandiflora were shown basically by non-polar extract fraction, with $\mathrm{LC}_{50}$ were $29.19 \mathrm{ppm}, 18.84 \mathrm{ppm}, 22.17 \mathrm{ppm}$ and $546.53 \mathrm{ppp}$, respectively. Mainwhile, characteristic of antimollusk of $S$. sesban was basically shown by polar extract fraction, with $\mathrm{LC}_{50}$ was $164.55 \mathrm{ppm}$. The active antimollusk compaun groups of $C$. gigantea, $C$. rotundus, $P$. angulata, $S$. grandiflora and $S$. sesban were alkaloid, steroid, asam fenolat, dan saponin, respective.
\end{abstract}

Kata-kata kunci: rice plant, antimollusk, gold snail, cultivar, diversity of mollusk, and paddy field 


\section{PENDAHULUAN}

$\mathrm{D}$ i Indonesia, keong mas semula dibudidayakan untuk penghias atau untuk konsumsi manusia. Namun saat ini keong mas telah menyebar ke beberapa propinsi termasuk Aceh, Sumatera Selatan, Jambi, Jawa Tengah, Bali dan Nusa Tenggara Barat, dan menjadi salah satu hama penting tanaman padi. Serangan keong mas biasanya semakin meluas seiring dengan turunnya hujan. Populasi keong mas bisa menurun pada saat terjadi kemarau yang berkepanjangan, namun setelah hujan mulai turun, serangan keong mas kembali meluas (Anon., 2005; Anon., 2007).

Keong mas merupakan gastropoda air tawar yang habitat asalnya di daerah Amerika Selatan (Edra, 1989) dan di Indonesia keong mas merupakan hewan pendatang baru, yang semula dipelihara untuk penghias di akuarium dan kemudian dipelihara di kolam-kolam untuk konsumsi manusia. Namun saat ini di beberapa propinsi di indonesia, keong mas telah menyebar ke sawah-sawah dan menjadi hama tanaman terutama tanaman padi (Suripto et al., 2005). Beberapa laporan telah memperkenalkan nama-nama ilmiah untuk keong mas yang saat ini ada di Indonesia, diantaranya adalah Pomacea canaliculata, $P$. cuprina, $P$. doliodes, P. gigas, P. glacula, P. insularia, dan $P$.lineata (Edra, 1989; Sastroutomo, 1990 dalam Suripto et al., 2005; Munandar, 1993).

Menurut Ristiyanti (1992 dalam Munandar 1993), ada dua jenis keong yang sering dijumpai di lahan sawah padi di Indonesia saat ini. Jenis pertama ukurannya lebih kecil (diameter cangkangnya tidak lebih dari $5 \mathrm{~cm}$ ), cangkangnya berwarna kuning keemasan, menara cangkang tinggi dengan kanal yang dalam. Rumpun telurnya berwarna putih kecoklatan. Reproduksinya lamban, hanya bertelur dua kali setiap bulan. Keong mas ini tidak rakus, dan hanya menyukai tanaman air yang lunak. Keong mas dengan ciri-ciri ini menurut Machfudz dan Ristiyanti, 1992 dalam Munandar, 1993), nama jenisnya disebut $P$. canaliculata. Jenis keong mas yang kedua ukurannya lebih besar (diameter cangkangnya 5 hingga $8 \mathrm{~cm}$ ) warna cangkang kuning kusam, menaranya rendah dengan kanal yang dalam. Laju reproduksinya sangat cepat, dapat bertelur 4 hingga 8 kali perbulan. Setiap kali bertelur dapat menghasilkan 25 hingga 320 butir telur dengan masa inkubasi bervariasi, yaitu 10 hingga 15 hari, tergantung pada suhu dan mikrolingkungannya. Rumpun telurnya berwarna merah, sehingga keong mas ini sering disebut keong murbai. Keong mas ini sangat rakus dan berpotensi menjadi hama perusak tanaman. Dalam penelitian ini digunakan jenis keong mas yang disebutkan ke dua yaitu jenis Pomacea speciosa.

Kedudukan keong mas yang digunakan dalam penelitian ini dalam sistematika hewan menurut Adalla-MoralloRejesus, 1989; Machfudz, 1992 dalam Munandar, 1993) adalah sebagai berikut: (1) Filum : Mollusca, (2) Kelas : Gastropoda, (3)Bangsa : Caenogastropoda, (4) Suku : Pilidae, (5) Marga : Pomacea, dan (6) Jenis : Pomacea speciosa.

Di Filipina keong mas tumbuh dan berkembang 10 kali lebih cepat dari keong pribumi (Lacanilao 1990). Keong mas'mempunyai masa hidup dua hingga tiga tahun. Periode reproduksinya sangat panjang, yaitu mulai dari usia dua bulan setelah keluar dari telur sampai berumur dua sampai tiga tahun (Saxena et al., 1990; Guerrero, 1989).

Fase paling kritis serangan keong mas terhadap tanaman padi sangat pendek, yaitu saat padi masih di pesemaian sampai tanaman padi berumur tiga minggu setelah tanam. Hal ini karena batang dan daun padi dalam kisaran umur tersebut belum banyak mengandung silika sehingga bersifat lunak dan lebih disukai oleh keong mas (Sumangil, 1989). Dalam waktu 10 hingga 15 menit, seekor keong mas dapat memakan habis satu rumpun padi berumur 20 hari setelah tanam. Tanaman padi yang berumur lebih dari satu 
bulan tidak tampak adanya kerusakan yang berat walaupun ditempati keong oleh mas, dibanding tanaman padi yang yang berumur kurang dari satu bulan. Atienza \& Adalla (1989) juga telah melaporkan, bahwa pemindahan bibit padi setelah ke lahan pertanaman setelah berumur lebih dari 40 hari dapat mengurangi resiko kerusakan tanaman padi akibat serangan keong mas. Berdasarkan hasil percobaan di laboratosium , keong mas dapat menyebabkan tingkat kerusakan yang sama pada beberapa kultivar padi seperti IR-64, Pelita, Cisanggarung dan Cipunagara (Suripto et al., 2005).

Sampai sejauh ini, keong mas di Filipina selain merusak tanaman padi, dilaporkan juga mampu memakan dan merusak tanaman-tanmanan penting yang lain seperti jagung dan jeruk . Juga dilaporkan, bahwa sekitar 25 jenis tanaman dapat dimakan oleh keong mas ini (Atienza \& Adalla,1989). Penanggulangan keong mas secara biologis juga pernah dilakukan dengan cara melepaskan hewan itik atau babi ke lahan sawah padi. Namun cara ini hanya dapat dilakukan pada lahan tanaman padi yang sudah dewasa atau setelah tanaman padi sudah dipanen (Suripto et al., 2008).

Perhatian manusia terhadap bahan molusisida alami asal tumbuhan sudah dimulai sejak tahun 1930-an, yaitu sejak ditemukannya siput air tawar sebagai vektor skistosomiasis (Kloos \& McCullough 1987). Namun, pengendalian siput vektor tersebut yang dilakukan dengan menggunakan molusisida sintesis dapat mengakibatkan timbulnya permasalahan baru berupa kematian organisme lain yang bukan sasaran, sementara resistensi siput sasaran menjadi meningkat.

Lebih dari 1000 jenis tumbuhan, termasuk 600 jenis di Cina telah diuji aktivitas molusisidanya. Namun hanya sebagian kecil yang digunakan langsung untuk pengendalian siput. Hal tersebut karena sebagian besar diketahui tidak efisien (memerlukan konsentrasi aplikasi yang sangat tinggi), tidak mudah dilakukan oleh petani (bagian tumbuhan yang terlalu keras untuk digiling), menimbulkan efek samping yang tidak menyenangkan seperti spekrum sitotoksik yang sangat lebar, kelarutan rendah dalam air, dan tidak mudah terdegradasi di alam setelah aplikasi, dan sebgaian lagi belum diketahui spektrum efek toksiknya sehingga belum direkomendasikan untuk penggunaan langsung di lapangan (Kloos \& McCullough, 1987; Marston \& Hostettmann, 1985.

Penelitian sifat anti moluska perlu diarah untuk menemukan jens-jenis tumbuhan yang memilki aktivias anti moluska dengan spektrum efek toksik yang sempit (selektivitas secara fisiolgis tinggi) untuk mengendalikan jenis moluska hama, seperti keong mas hama tanaman padi. Dalam pencarian molusisida tumbuhan yang efektif dan selektif, ada empat kecenderungan yang dapat diidentifikasi: Tumbuhan digunakan dalam bentuk ekstrak atau ditempatkan langsung dalam habitat siput: bahan aktif diidentifikasi dan diisolasi; bahan tumbuhan diperiksa lebih lanjut untuk menentukan stabilitasnya di bawah kondisi fisiokimia lapangan dan toksisitasnya terhadap siput sebagai organisme sasaran dan terhadap organisme lainnya yang bukan sasaran pengendalian (Kloos \& McCullough, 1987). Karaktersitika yang digunakan sebagai dasar pemilihan tumbuhan sebagai sumber molusisida adalah meliputi (Adewunmi \& Sofowora, 1980; Hamburger \& Hostettmann, 1991).

Berdasarkan petunjuk mengenai hubungan antara golongan senyawa dengan aktivitasnya sebagai agen anti moluska, maka bahan aktif anti moluska dari tanaman dapat ditarik dengan menggunakan teknik ekstraksi secara bertingkat, dengan menggunakan seri pelarut yang kepolarannya meningkat. Menurut Harborne (1987), ekstraksi bertingkat dimaksudkan untuk mendapatkan bahan aktif tertentu dengan kadar lebih tinggi pada fraksi tertentu bila dibandingkan dengan hasil ekstraksi tunggal. 
Berbagai langkah penanggulangan keong mas di sawah padi sebenarnya telah dilakukan. Pengendalian keong mas secara mekanik dan biologis, seperti yang pernah dilakukan di Filipina dengan cara pemasangan perangkap telur, pemungutan langsung dan pengerahan itik ke sawah padi dirasakan kurang praktis, karena keong mas telah menyebar dan menempati lahan yang sangat luas (Guzman \& Enriquez 1989; Imperial, 1989; Kenmore, 1989; Sumangil,1989). Pengendalian keong mas secara kimiawi juga pernah dilakukan, yaitu dengan Brestan dan Dimotrin, namun penggunaanya terbatas karena dapat mencemari sawah dan menyebabkan kematian ikan-ikan di sawah (Suripto et al., 2008). Untuk menekan timbulnya masalah pencemaran dalam pengendalian keong mas ini maka perlu dipelajari pemakaian molusisida dari sejumlah jenis tumbuhan asal Indonesia yang berpotensi memiliki aktivitas anti moluska.

Penelitian ini diarahkan untuk mengembangkan pemberdayaan sejumlah jenis tumbuhan anti moluska yang efektif, aman lingkungan dan feasible bagi petani untuk mengendalikan keong mas hama tanaman padi. Tujuan khusus dari penelitian ini adalah sebagai berikut: (1). Mengkofirmasi golongan senyawa yang aktif anti moluska dari masing-masing fraksi ekstrak tumbuhan yang dipelajari. (2). Mengetahui preferensi dan kecepatan makan dari berbagai usia keong mas terhadap berbagai kultivar dan umur tanaman padi. berbagai kategori sawah padi hubungannya dengan invasi keong mas dan aplikasi molusisida. (4). Mengetahui toksisitas akut letal dari setiap fraksi ekstrak tumbuhan yang dipelajari terhadap keong mas. (5). Mengetahui selektivitas molusisida secara fisiologis dari masing-masing jenis tumbuhan tersebut berdasarkan toksisitasnya terhadap kelompok organismo non-sasaran, yang meliputi ikan mas dan tanaman padi. (6). Mengetahui stabilitas bahan molusisida ekstrak dari masing-masing jenis tumbuhan yang dipelajari selama waktu penyimpanan dan selama waktu aplikasi. Tujuan 5 dan 6 ingin dicapai pada penelitian periode tahun ke dua.

\section{BAHAN DAN METODE}

\section{Seleksi dan Koleksi Bahan Tumbuhan Anti Moluska}

Seleksi jenis tumbuhan anti moluska yang akan dievaluasi kinerja anti moluskanya untuk mengendalikan keong mas hama tanaman padi didasarkan atas kriteria seleksi tumbuhan molusisida menurut Adewumi \& Sofowora (1980) dan dikembangkan oleh Hamburger \& Hostettmann (1990), dan potensial untuk dikembangkan di Indonesia (Suripto, et al., 2008).

Berdasarkan kriteria tersebut di atas, maka ditetapkan lima jenis tumbuhan anti moluska yang akan dievaluasi kinerja anti moluskanya dalam penelitian ini, yaitu sebagai berikut (Tabel 1). (3). Keanekaragaman jenis moluska di

Tabel 1. Daftar nama jenis tumbuhan anti moluska yang dipelajari

\begin{tabular}{|c|l|l|l|c|}
\hline No. & Nama Jenis & Nama Lokal & Suku & $\begin{array}{c}\text { Organ yang } \\
\text { Digunakan }\end{array}$ \\
\hline 1. & Calotropis gigantea & Biduri & Euphorbiaceae & daun \\
\hline 2. & Cyperus rotundus & Teki & Cyperaceae & daun \\
\hline 3. & Physalis peruviana & Cecendet & Fabaceae & daun \\
\hline 4. & Sesbania grandiflora & Turi & Fabaceae & daun \\
\hline 5. & Sesbania sesban & Jayanti & Fabaceae & daun \\
\hline
\end{tabular}


Keong mas yang akan digunakan dalam penelitian ini bibitnya dikoleksi dari daerah pesawahan di desa Tanjung. Keong mas ini dikembangbiakkan dari ekotpe yang ganas dengan ciri rumpun telurnya berwarna merah, warna cangkangnya kuning kusam, menara cangkang pendek dengan kanal yang dalam. Ikan mas dikoleksi dari kolam ternak di Desa Sayang-sayang Lombok Barat.

Untuk uji mortalitas di laboratorium, keong mas dan ikan mas yang digunakan masing-masing mempunyai usia dan ukuran yang berimbang, yaitu usia keong mas sekitar satu bulan dengan diameter cangkang sekitar $1 \mathrm{~cm}$, sedangkan usia ikan mas sekitar dua bulan dengan ukuran bobot tubuh sekitar 80 gram. Sedangkan untuk uji preferensi dan kecepatan makan, keong mas yang digunakan berasal dari tiga kelompok usia, 1, 3 dan 6 bulan. Sebelum uji hayati dilakukan, semua hewan uji diaklimatisasi terlebih dahulu dalam kondisi-kondisi yang sama dengan kondisi percobaan di akuarium.

Untuk uji hayati setiap fraksi ekstrak yang dihasilkan pada pertumbuhan tanaman padi, digunakan kultivar padi Ciherang. Sedangkan untuk uji preferensi dan kecepatan makan dari keong mas, digunakan tiga kultivar tanaman padi, yaitu Cibogo, Cigeulis, dan Ciherang, masing-masing dalam tiga umur tanaman padi, yaitu 10, 20, dan 60 hari setelah tanam.

\section{Ekstraksi Bertingkat}

Guna menarik senyawa aktif anti moluska, dalam hal ini khususnya dari golongan saponin triterpen dari simplisia, maka akan dilakukan ekstraksi cair-padat secara bertingkat, dengan menggunakan seri pelarut yang kepolarannya meningkat berturut-turut, yaitu petroleum eter $(\mathrm{PE})$, diklorometan (DCM), dan etanol (EtOH). Pemilihan pelarut berdasarkan tingkat kepolarannya ini bertujuan untuk melarutkan semua golongan senyawa aktif dari simplisia sesuai dengan kepolarannya. Setiap tahap ekstraksi dilakukan dengan cara maserasi simplisia, yang dilanjukan dengan soxhletasi sesuai dengan prosedur yang dikembangkan oleh Harborne (1987 dalam Suripto et al., 2008). Ekstrak murni masing-masing fraksi diperoleh dengan cara menguapkan pelarut pada tingkat ekstraksi yang bersangkutan, dengan menggunakan penguap putar vakum dan setelah dipindahkan ke dalam cawan, ekstrak kental yang dihasilkan dikesatkan lebih lanjut di dalam ruang penguapan.

Sebelum digunakan untuk uji hayati, masing-masing fraksi ekstrak yang dihasilkan diperiksa kandungan aktif anti moluskanya, dalam hal ini khusunya golongan saponin triterpen dengan menggunakan kromatografi lapis tipis (KLT), menurut metode yang dikembangkan Harborne (1987 dalam Suripto et al., 2008), yang menggunakan pelat silika gel G/uv 254 nm sebagai fase diam dengan sistem pengembang satu arah. Pada KLT yang menggunakan fase pengembang heksanEtOAc (1:1) dan dengan penampak bercak $\mathrm{CHCl3}$, sampel yang memperlihatkan bercak dengan warna kuning dan coklat merah menandai adanya golongan senyawa saponin. KLT juga dilakukan dengan menggunakan pengembang $\mathrm{BuOH}-\mathrm{H} 2 \mathrm{O}$ (1:1), yang akan menghasilkan serapan di bawah \& $254 \mathrm{~nm}$, untuk membandingkan bilangan rf setiap sampel ekstrak dengan saponin strandar.

\section{Preferensi dan Kecepatan Makan oleh Keong Mas Terhadap Tanaman Padi}

Uji preferensi dan kecepatan makan oleh keong mas terhadap tanaman padi dilakukan dengan menggunakan rancangan blok acak lengkap menurut variasi usia keong mas ( 1, 3 dan 6 bulan setelah menetas dari telur) dan variasi kultivar (Cibogo, Cigelis, dan Ciherang) serta umur (10, 20,dan 60 hari setelah tanam) tanaman padi. Variabel yang diamati untuk preferensi adalah frekuensi jumlah rumpun masingmasing kultivar dan umur tanaman padi yang dirusak oleh keong mas berbagai usia. Variabel yang diamati untuk kecepatan 
makan adalah bobot tanaman padi berbagai kultivar dan umur yang dimakan per rumpun per hari oleh keong mas menurut variasi usia. Data diolah secara deskriptif untuk menggambarkan usia keong mas yang relatif paling berbahaya terhadap tanaman padi dan menggambarkan kultivar dan umur tanaman padi yang relatif paling rentan terhadap serangan keong mas.

\section{Keanekaragaman Jenis Moluska Berbagai Kategori Lahan Sawah Padi}

Pengamatan keanekaragaman jenis moluska diamati pada tiga kategori lahan sawah padi, yaitu sawah yang diinvasi keong mas dan diaplikasikan molusisida, sawah yang diinvasi keong mas tetapi tidak diaplikasikan molusisida, dan sawah yang tidak diinvasi oleh keong mas. Untuk masing-masing kategori diambil tiga contoh areal lahan sawah.

Dari masing-masing contoh areal lahan sawah, pengamatan dilakukan dalam 10 plot kuadrat $1 \mathrm{~m}^{2}$ yang disebar secara acak. Contoh setiap jenis moluska yang diketemukan dalam semua contoh area diidentifikasi di Laboratorium Biologi Universitas Mataram. Data kepadatan (jumlah individu per plot) setiap jenis diolah untuk menentukan keanekaragaman jenis moluska (indeks Shannon-Winner) di setiap contoh aeral pada masing-masing kategori lahan sawah padi.

\section{Uji Hayati}

Uji hayati setiap fraksi ekstrak dari masing-masing jenis tumbuhan anti moluska yang dipelajari dilakukan terhadap keong mas menurut metode standar dari APHA (Clesceri et al. , 1989 dalam Suripto et al., 2008). Masing-masing unit uji hayati ini dilakukan menurut rancangan percobaan acak lengkap dengan menggunakan enam taraf konsentrasi perlakuan ekstrak, dan setiap perlakuan menggunkan menggunakan empat ulangan. Data mortalitas keong mas dari masing-masing unit uji hayati diolah dengan menggunakan program analisis probit
(Busvine-Nash, 1974 dalam Suripto et al., 2008) untuk menentukan LC $_{50}$ (konsentrasi yang menyebabkan kematian $50 \%$ populasi hewan uji) masing-masing eksrak tumbuhan uji terhadap keong mas. Cara kerja (mode of action) anti moluska dari bahan molusisida masing-masing ekstrak tumbuhan ini juga dipelajari.

\section{Analisis Data}

Data preferensi dan kecepatan makan keong mas diolah secara deskriptif untuk menggambarkan usia keong mas yang relatif paling ganas dan kultivar serta umur tanaman padi yang relative paling rentan terhadap serangan keong mas. Data keanekaragaman jenis moluska juga diolah secara deskriptif untuk menggambarkan pengaruh invasi keong mas dan aplikasi molusisida terhadap keanekaragaman jenis moluska di sawah padi. Data mortalitas keong mas di masingmasing unit uji hayati fraksi ekstrak tumbuhan studi diolah dengan menggunakan program analisis probit untuk menentukan $\mathrm{LC}_{50}$, yaitu konsentrasi yang mematikan $50 \%$ hewan uji.

\section{HASIL DAN PEMBAHASAN}

\section{Preferensi Makan oleh Keong Mas Terhadap Tanaman Padi}

Tingkat kesukaan atau pemilihan (preferensi) makan oleh keong mas terhadap tanaman padi menurut variasi cultivar dan umur tanaman padi juga dapat dijadikan sebagai salah satu dasar untuk membuat strategi ekologis pengendalian keong mas hama tanaman padi. Hasil menunjukan, bahwa variasi cultivar tanaman padi, dalam hal ini cultivar Cibogo, Cigeulis, dan Ciherang tidak menyebabkan perbedaan yang berarti terhadap tingkat kesukaan keong mas untuk memakan tanaman padi tersebut. Hasil tersebut mendukung hasil pengamatan sebelmnya ang dilakukan terhadap kultivarkultivar tanaman padi yang lain seperti C4, PELITA, dan Cipunara (Anon, 2003). 
Sebaliknya, faktor umur tanaman padi (berlaku pada semua kultivar yan diuji) sangat mempengaruhi tingkat kesukaan keong mas makan tanaman padi tersebut. Tanaman padi usia 10 hari setelah tanam kira-kira delapan kali lebih disukai oleh keong mas dibanding tanaman padi usia 60 hari setelah tanam. Tanaman padi usia dua bulan juga masih termasuk sangat disukai keong mas, yaitu sekitar tujuh kali lebih disukai dibanding tataman padi usa 60 hari (Gambar 1).

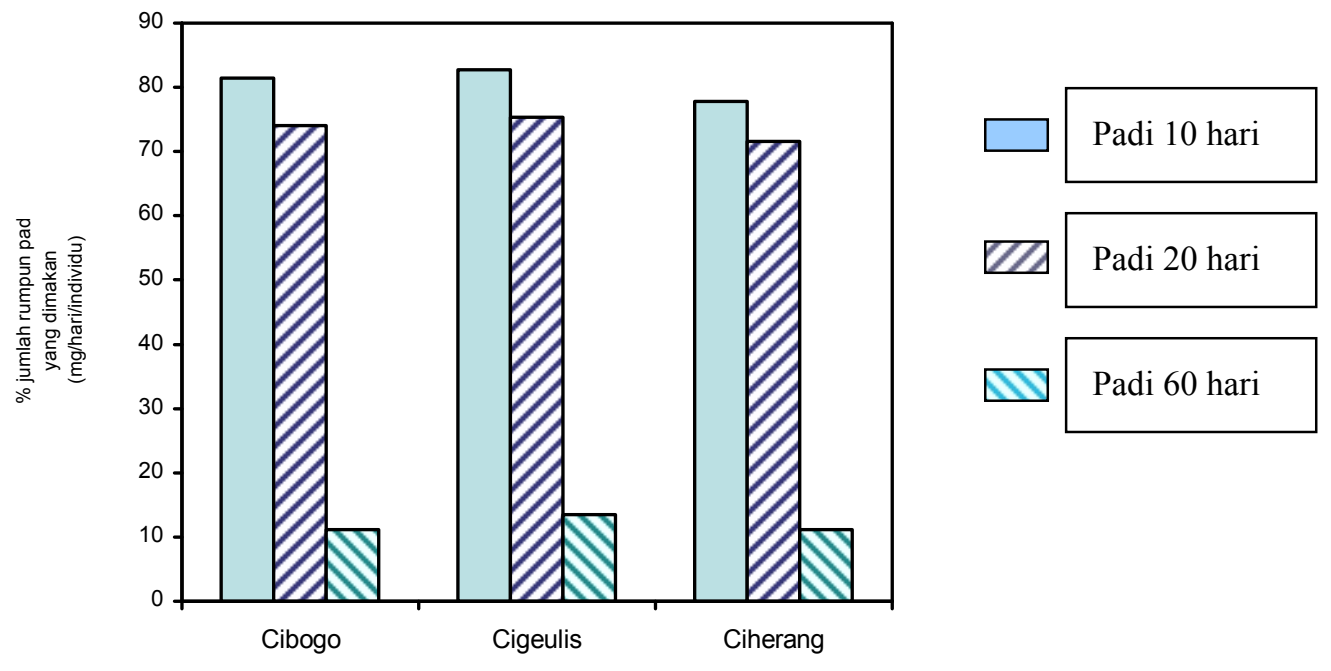

Gambar 1. Preferensi makan oleh keong mas menurut variasi kultivar dan umur tanaman padi.

Hasil di atas menunjukkan, bahwa masa kritis tanaman padi terhadap serangan keong mas adalah pada masa tanaman padi berumur kurang dari 20 hari. Dengan demikian, aplikasi mlusisida untuk mengendalikan keong mas hama tanaman padi sebaiknya dilakukan pada masa tanaman padi sebelum berumur 20 hari setelah tanam.

\section{Kecepatan Makan dari Keong Mas Terhadap Tanaman Padi}

Sebagai salah satu dasar untuk membuat strategi ekologis pengendalian keong mas hama tanaman padi adalah informasi mengenai tingkat kerakusannya, dalam hal ini kecepatan makan menurut variasi usia keong mas terhadap berbagai kultivar tanaman padi. Hasil menunjukan, bahwa kecepatan makan tanaman padi (bobot tanaman padi yang dimakan per hari oleh per individu keong mas) oleh keong mas usia enam bulan adalah dua kali lebih tinggi dari keong mas usia tiga bulan atau empat kali lebih tinggi dari keong mas usia satu bulan (Gambar 2). 


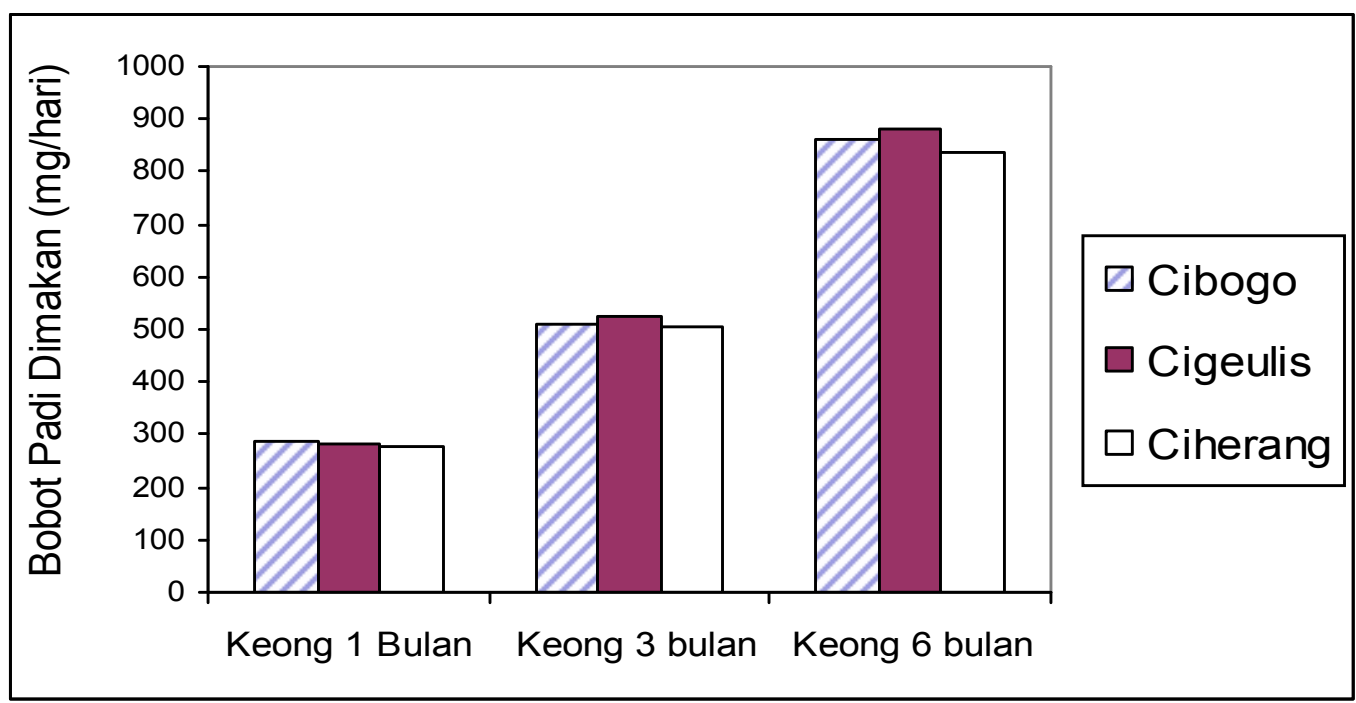

Gambar 2. Kecepatan makan oleh berbagai usia keong mas terhadap berbagai kultivar tanaman padi.

Namun demikian, di lapangan keog mas usia tiga bulan adalah kelompok usia yang relatif paling berbahaya karena kepadatannya yang jauh lebih tinggi (sekitar 10 kali) dari kelompok usia enam bulan. Variasi kultivar tanaman padi yang diuji, dalam hal ni kultivar Cibogo, Cigeulis, dan Ciherang tidak menyebabkan perbedaan yang berarti terhadap kecepatan makan dari keong mas tersebut (Gambar 3). Laporan lain menyebutkan, bahwa keong mas dewasa bisa empat kali lebih rakus dari keong mas anakan (usia 1 hingga 2 bulan)(Anon., 2007). Dengan demikian, pengendalian keong mas dapat digunakan dengan srategi yang sama untuk ke tiga kultivar tanaman padi tersebut.

\section{Keanekaragaman Jenis Moluska Di Sawah Padi yang Dinvasi Keong Mas dan Diaplikasikan Molusiisida}

Keanekaragaman jenis moluska diamati pada tiga kategori sawah padi, yaitu sawah yang diinvasi keong mas dan diaplikasikan molusisida, sawah yang diinvasi keong mas tetapi tidak diaplikasikan molusisida, dan sawah yang tidak diinvasi oleh keong mas.

Hasil menunjukkan, bahwa perpedaan keanekaragaman jenis moluska di berbagai sawah padi yang diamati tidak berhubungan dengan kategori ada tidaknya invasi keong mas maupun diaplikasikan atau tidaknya molusisida. Perbedaan keanekaragaman jenis moluska berbagai sawah padi yang diamati lebih disebabkan oleh perbedaan sampel (ulangan) sawah yang berhubungan dengan perbedaan lokasi, dan bukan oleh pebedaan kategori tersebut di atas (Tabel 2, Gambar 3). 
Tabel 2. Keanekaragaman jenis moluska di berbagai kategori sawah padi

\begin{tabular}{|c|c|c|c|c|c|}
\hline \multicolumn{2}{|c|}{$\begin{array}{c}\text { Tempat dan } \\
\text { Jumlah Kuadrat }\end{array}$} & Kategori Sawah & $\begin{array}{c}\text { Jumlah } \\
\text { Jenis }\end{array}$ & Nilai H' & Jenis Moluska Dominan \\
\hline Tanjung & 10 & $\begin{array}{l}\text { Diinvasi keong mas } \\
\text { dan diaplikasikan } \\
\text { Molusisida } \\
\text { (Kategori A) }\end{array}$ & 4 & 0,3192 & Pomacea canaliculata \\
\hline Gondang & 10 & sda & 5 & 0,5503 & Pomacea canaliculata \\
\hline Pemenang & 10 & sda & 4 & 0,3530 & Pomacea canaliculata \\
\hline $\begin{array}{l}\text { Karang } \\
\text { Pule }\end{array}$ & 10 & $\begin{array}{l}\text { Diinvasi keong mas } \\
\text { tetapi tidak } \\
\text { diaplikasikan } \\
\text { molsisida } \\
\text { (Kategori B) }\end{array}$ & 5 & 0,4000 & Pomacea canaliculata \\
\hline Pagutan & 10 & sda & 5 & 0,32300 & Pomacea canaliculata \\
\hline Pejanggik & 10 & $\begin{array}{l}\text { sda } \\
\text { Tidak diinvasi }\end{array}$ & 3 & 0,3650 & Pamilia ariana \\
\hline Jonggat & 10 & $\begin{array}{l}\text { keong mas } \\
\text { (Kategori C) }\end{array}$ & 4 & 0,2600 & Melonoides sp. \\
\hline Sukarara & 10 & sda & 5 & 0,6217 & Melonoides sp. \\
\hline Pujut & 10 & sda & 5 & 0,5917 & Elimia $s p$. \\
\hline
\end{tabular}

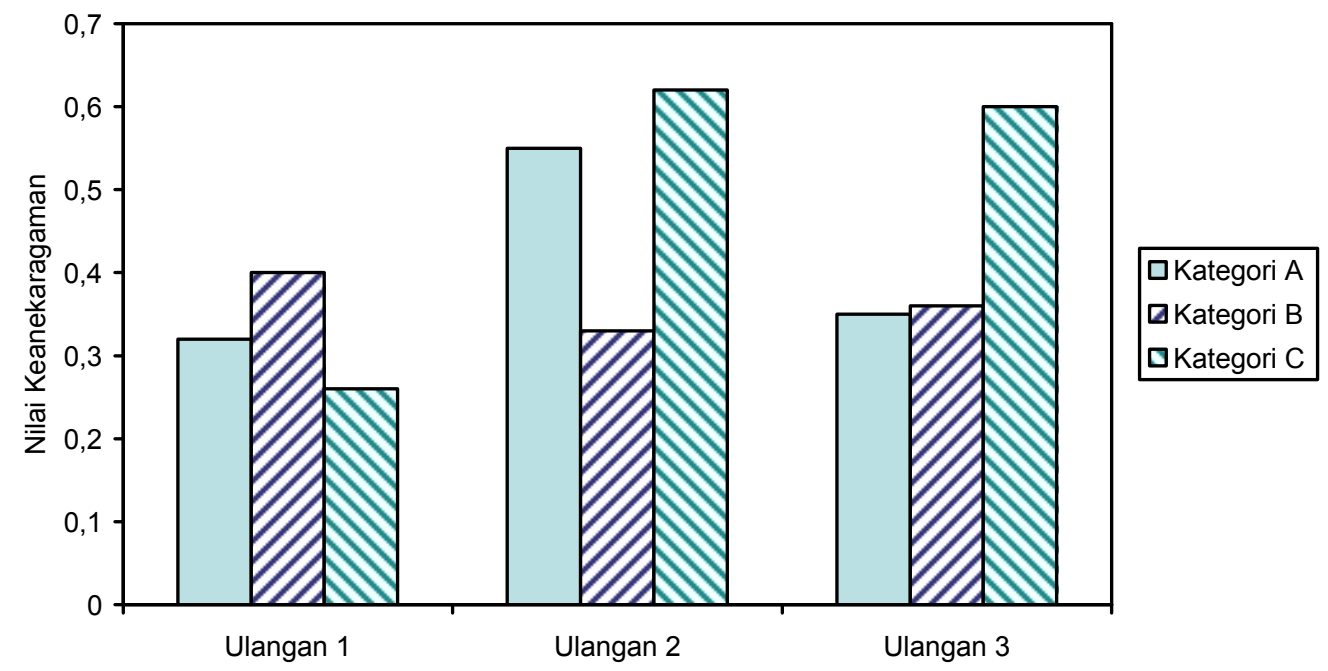

Gambar 3. Keanekaragaman jensi moluska pada berbagai kategori sawah padi

Hasil di atas mempunyai makna, bahwa penekanan populasi keong mas tidak berpotensi mengubah keanekaragaman jenis moluska di sawah padi tersebut. Demikian pula penggunaan molusisida, ternyata tidak menyebabkan berkurangnya nilai keanekaragaman jenis moluska. Hal tersebut mungkin karena bahan molusisida berupa saponin yang digunakan mudah dan cepat terdegradasi dalam air selama aplikasi. Pada hasil uji hayati juga ditunjukkan, bahwa larutan ekstrak daun S. sesban sebagai bahan anti moluska alami setelah dibiarkan selama 24 jam dalam air menjadi tidak aktif lagi (mortalitas keong mas 0\%). Sesuai dengan penelitian sebelumnya (Suripto et al., 2005; Suripto et al., 2007) bahwa disamping memiliki selektivitas fisiologis yang tinggi, bahan aktif anti moluska dari fraksi ekstraketanol dari daun $S$. sesban juga cukup stabil selama penyimpanan ekstrak satu bulan dan 
dalam simplisia selama penyimpanan tidak lebih dari satu tahun.

Toksisitas Akut Letal dari Berbagai Fraksi Ekstrak Daun Tumbuhan Anti Moluska

Semua fraksi ekstrak daun dari masing-masing jenis tumbuhan anti moluska yang dipelajari bersifat toksik letal terhadap keong mas, namun dengan toksisitas berbeda. Dari daun $C$. gigantea, fraksi ekstrak-heksan dengan konsentrasi 10 ppm sudah menyebabkan kematian keong mas, sedangkan pada fraksi air, kematian keong mas mulai tampak pada konsentrasi 156 ppm (Gambar 4 dan 5).

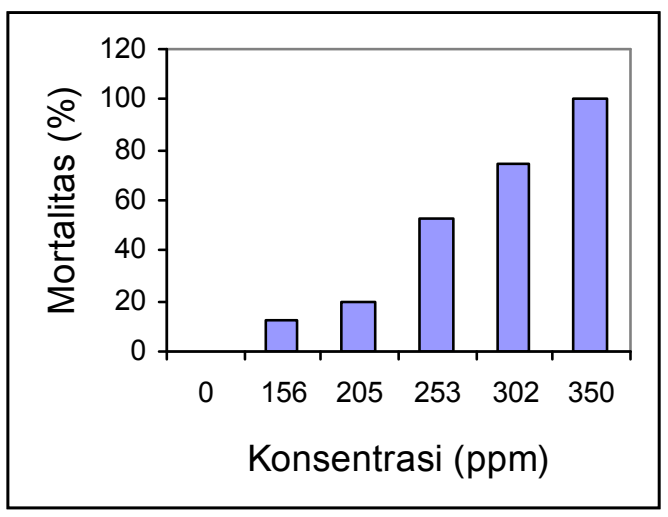

Gambar 4. Mortalitas keong mas pada perlakuan fraksi ekstak-air dari daun $C$. gigantea

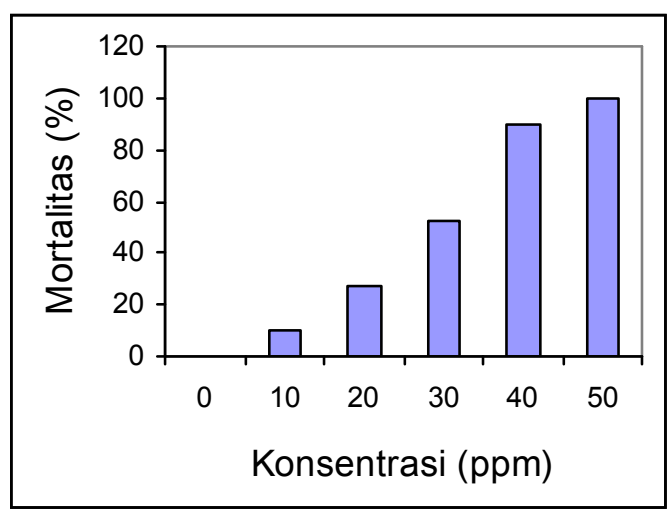

Gambar 5. Mortalitas keong mas pada perlakuan fraksi ekstak-heksan dari daun C. gigantea
Dari daun C. rotundus, fraksi ekstakheksan dengan konsentrasi 5 ppm sudah menyebabkan kematian keong mas, sedangkan pada fraksi air, kematian keong mas mulai tampak pada konsentrasi 1198 ppm (Gambar 6 dan 7).

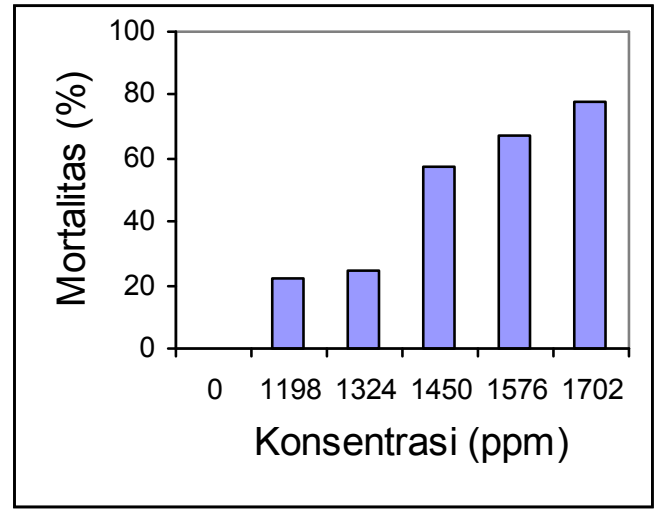

Gambar 6. Mortalitas keong mas pada perlakuan fraksi ekstak-air dari daun C. rotundus

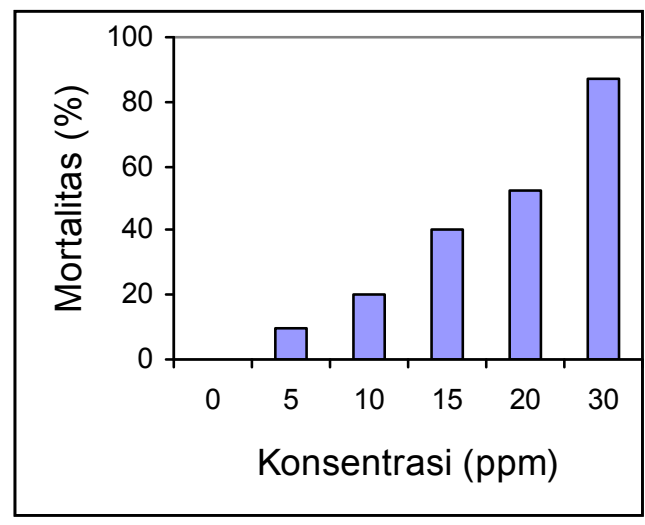

Gambar 7. Mortalitas keong mas pada perlakuan fraksi ekstak-heksan dari daun C. rotundus 
Dari daun $P$. angulata fraksi ekstakheksan dengan konsentrasi 5 ppm sudah menyebabkan kematian keong mas,

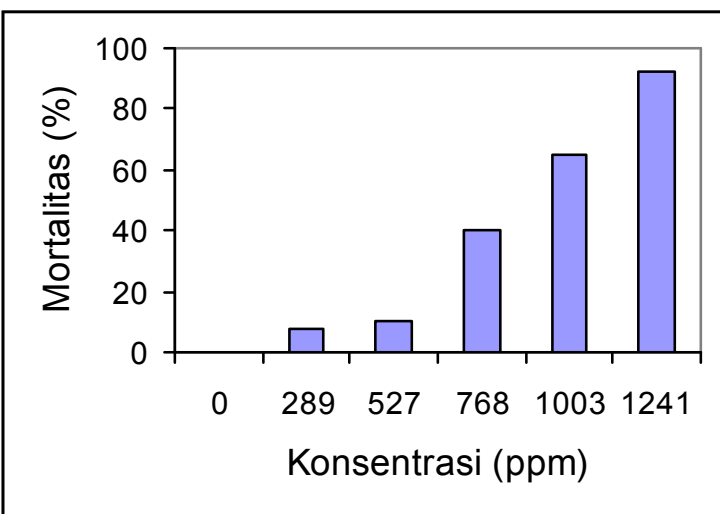

Gambar 8. Mortalitas keong mas pada perlakuan fraksi ekstak-air dari daun $P$. angulata

Dari daun $S$. grandiflora fraksi ekstrak-air dan fraksi ekstrak-heksan mempunyai toksisitas yang relatif sama terhadap keong mas, yaitu pada konsentrasi sedangkan kematian keong mas pada fraksi air mulai tampak pada konsentrasi 289 ppm

(Gambar 8 dan 9).

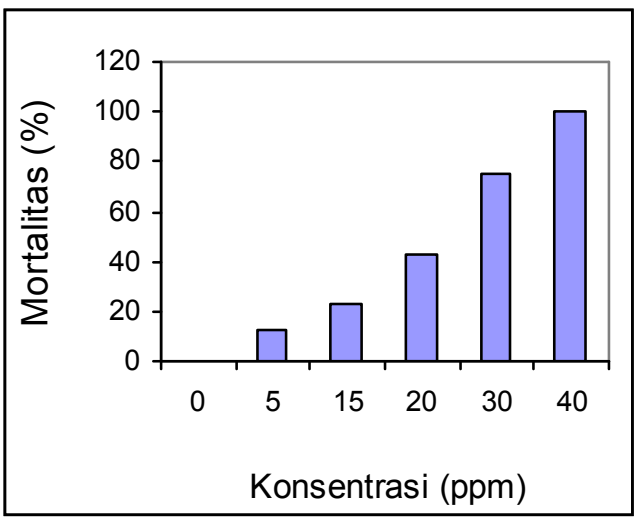

Gambar 9. Mortalitas keong mas pada perlakuan fraksi ekstak-heksan dari daun $P$. angulata

200 ppm frasi ekstrak-hesan atau 271 ppm fraksi ekstrak-air masing-masing sudah menyebabkan kematan keong mas sekitar 10\%. (Gambar 10 dan 11).

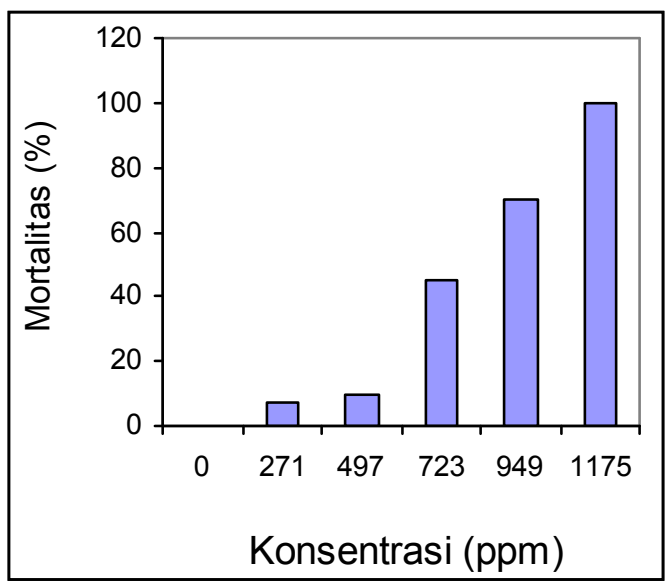

Gambar 10. Mortalitas keong mas pada perlakuan fraksi ekstak-air dari daun S. grandiflora

Dari daun S. sesban fraksi ekstak-air dengan konsentrasi 157 ppm sudah menyebabkan kematian lebih dari 50\% keong

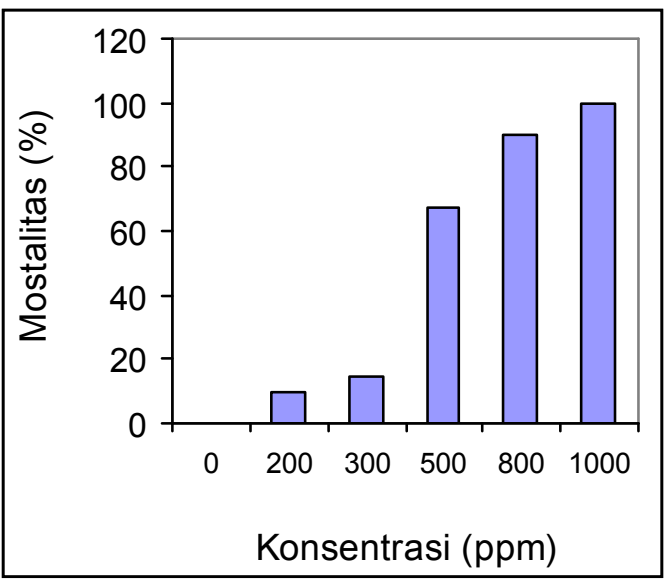

Gambar 11. Mortalitas keong mas pada perlakuan fraksi ekstak-heksan dari daun S. grandiflora

mas, sedangkan pada fraksi-heksan, kematian keong mas sekitar $10 \%$ mulai tampak pada konsentrasi 200 ppm (Gambar 12 dan 13). 


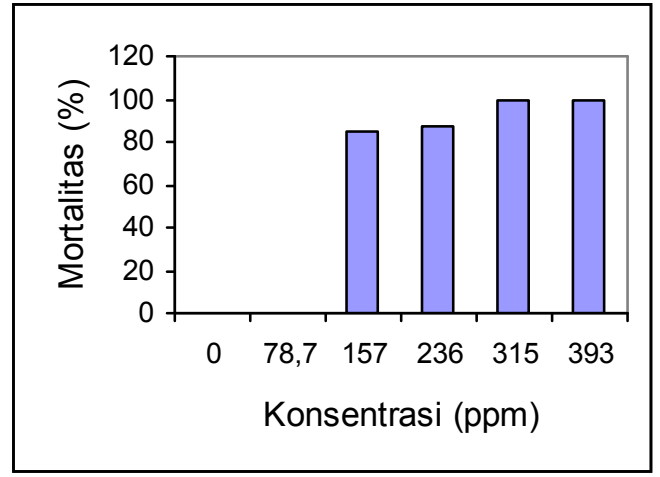

Gambar 13. Mortalitas keong mas pada perlakuan fraksi ekstak-air dari daun $S$. sesban

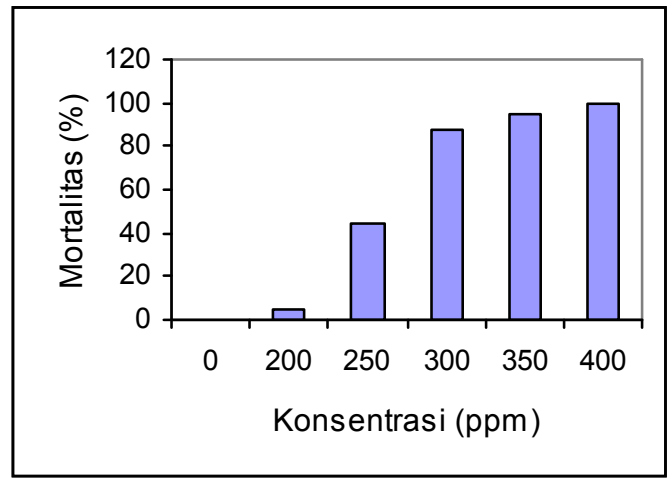

Gambar 14. Mortalitas keong mas pada perlakuan fraksi ekstak-heksan dari daun $S$. sesban
Berdasarkan hasil analisis probit diketahui, bahwa kandungan aktif anti moluska pada daun $C$. rotundus, $C$. gigantea, $P$. angulata dan $S$. grandiflora terutama terdapat pada fraksi ekstrak non-polar, yaitu fraksi-heksan. Hal ini karena fraksi ekstrakheksan masing-masing dari ke tiga jenis tumbuhan tersebut menunjukkan harga $\mathrm{LC}_{50}$ yang jauh lebih rndah, yang berarti toksisitasnya lebih tinggi dibanding fraksi ekstrak polarnya, yaitu fraksi ekstrak-air. Kandungan aktif anti moluska dari S. sesban relatif lebih tinggi pada fraksi polar, yaitu fraksi ekstrak-air. Harga $\mathrm{LC}_{50}$ fraksi ekstrakair dari daun tumbuhan tersebut lebih rendah daripada fraksi non polarnya, yaitu fraksi ekstrak-heksan. Harga LC50 dari ke dua fraksi ekstrak masing-masing jenis tumbuhan anti moluska terhadap keong mas yang dipelajari dapat dilihat pada Tabel 3.

Tabel 3. Konsentrasi letal dari berbagai fraksi ekstrak daun tumbuhan anti moluska terhadap keong mas.

\begin{tabular}{|l|c|c|}
\hline Jenis Tumbuhan & \multicolumn{2}{|c|}{$\mathrm{LC}_{50}(\mathrm{ppm})$} \\
\hline & Fraksi Ekstrak Air & Fraksi Ekstrak Heksan \\
\hline C. gigantea & 278,6215255 & 29,1943754 \\
C. rotundus & 1609,329251 & 18,84427546 \\
P. angulata & 1154,951951 & 22,17217696 \\
S. grandiflora & 978,2680486 & 546,5331833 \\
S. sesban & 164,4830967 & 231,5508686 \\
\hline
\end{tabular}

Berdasarkan pemeriksaan fitokmia diketahui, bahwa golongan senyawa dari $C$. gigantea, $C$. rotundus, $P$. angulata, $S$. grandiflora, dan $S$. sesban, yang terutama aktif anti moluska terhadap keong mas berturut-turut adalah adalah alkaloid, steroid, asam fenolat, dan saponin. Dari senyawasenyawa tersebut, bahan aktif anti moluska berupa saponin, dalam hal ini khususnya dari jenis $S$. sesban merupakan golongan senyawa 
yang mudah larut dalam air, sehingga mudah ditarik dengan menggunakan air. Kelarutan bahan molusisida yang tinggi dengan air ini merupakan kelebihan tersendiri, yaitu memudahkan petani untuk mengaplikasikan molusisida asal tumbuhan tersebut.

Namun demikian, tahapan penelitian perlu dilakukan selanjutnya untuk menjawab masalah selektivitas anti moluska dari molusisida asal tumbuhan tersebut. Dala hal ini spektrum efek toksik bahan molusisida terhadap organisme non sasaran seperti ikan air tawar dan tanaman padi perlu segera dipelajari. Demikian pula stabilitas bahan molusisida tumbuhan selama masa penyimpanan dan selama masa aplikasi perlu dipelajari karena merupakan aspek yang sangat penting bagi upaya peningkatan efisiensi dan upaya penyelamatan lingkungan.

\section{KESIMPULAN}

Preferesi keong mas terhadap tanaman padi tidak dipengaruhi oleh variasi kultivar akan tetapi dipengaruhi oleh umur tanaman padi. Tanaman padi 10 hari dan 20 hari lebih disukai oleh keong mas daripada tanaman padi 60 hari. Keong mas berusia enam bulan mempunyai kecepatan makan tanaman padi dua kali lipat dari keong mas berusia tiga bulan an empat kali lipat dari eong mas berusia satu bulan. Keberadaan keong mas dan aplikasi molusisida di lapangan tidak mempengaruhi keanekaragaman moluska di sawah padi.

Sifat anti moluska terhadap keong mas dari $C$. gigantea, $C$. rotundus, $P$. angulata dan $S$. grandiflora ditunjukkan terutama oleh fraksi ekstrak non-polar, sedangkan sifat anti muluska dari S. sesban terutama ditunjukkan oleh fraksi ekstrak polar. Golongan senyawa yang terutama aktif anti moluska dari $C$. gigantea, $C$. rotundus, $P$. angulata, S. grandiflora dan S. sesban berturut-turut adalah alkaloid, steroid, asam fenolat, dan saponin.

\section{DAFTAR PUSTAKA}

Adalla, C.B. \& B. Morrallo-Rejeus (1989). The golden apple snail, Pamacea sp. A pest of lowland rice in the Philippines. In : Sluges and Snails in World Agriculture ( Ed.:I Henderson). British Crop Protection Council.London. p: 417-422.

Adewunmi, C.O. \& E.A. Sofowora (1980). Preliminary screening of some plant extracts for molluscicidal activity. Planta Med. 39:57-65.

Anon. (2003) Kecepatan dan Preferensi Makan Keong Mas terhadap Tanaman Padi. Laporan tidak dipublikasikan. PAU Ilmu Hayati. Institut Tehnologi Bandung.

Anon. (2005). Hama keong mas serang ratusan hektar sawah. Republika online (01-07-2005).

http://www.republika.co.id

Anon. (2007). Keong mas serang tanaman padi. Kompas Cybermedia (24-012007). http://www.kompas.com

Atienza, F.C. \& C.B. Adalla ( 1989). Farmer's current control practies against the golden snail (Pomacea sp.) in the Philippines. In: Environmmental Impact of The Golden Snail (Pomacea sp.) on Rice Farming System in The Philippines (Eds:B. Ocosta \& R.S.V.Pullin ). International Center for Living Aquatic Resources Management. Manila p:13-14.

Edra, F.A. (1989). Introduction of the golden snail and escalation of its infestation of Philippine riceland. In: Environmental Impact of The Golden Snail ( Pomacea sp.) on Rice Farming System in The Philippines ( Eds.: B.O. Acosta \& R.S.V.Pullin ). International Center for Living Aquatic Resources Management. Manila p: 11-12. 
Guerrero, L. (1989). The biology og the golden snail in relation to Philippine conditions. In: Environmental Impact of The Golden Snail ( Pomacea sp.) on Rice Farming System in The Philippines ( Eds.: B.O. Acosta \& R.S.V.Pullin ). International Center for Living Aquatic Resources Management. Manila p: 10-11.

Guzman, E.D. \& F.B. Enriquez (1989). Nonchemical strategies to reduce golden snail damage to rice. In: Environmental Impact of The Golden Snail ( Pomacea sp.) on Rice Farming System in The Philippines ( Eds.: B.O. Acosta \& R.S.V.Pullin). International Center for Living Aquatic Resources Management. Manila p: 12-13.

Hamburger, M. \& K. Hostettmann (1991) . Bioactivity in plants: The link between phytochemistry and medicine phytochemistry. Phytochemistry. 30 (12):3864-3874.

Harborne, J.B. (1988). Introduction to Ecological Biochemistry. Academic Press London.

Imperial, E (1989) Practical management techniques to reduce golden snail damage in lowland rice. In: Environmental Impact of The Golden Snail ( Pomacea sp.) on Rice Farming System in The Philippines ( Eds.: B.O. Acosta \& R.S.V.Pullin). International Center for Living Aquatic Resources Management. Manila p: 14-15.

Kenmore, P. (1989). Control through farming methods. In: Environmental Impact of The Golden Snail ( Pomacea sp.) on Rice Farming System in The Philippines ( Eds.: B.O. Acosta \& R.S.V.Pullin). International Center for Living Aquatic Resources Management. Manila p: 7-8.
Kloos, H. \& F.S. McCullough (1987). Plant with recognized molluscicidal activity. In: Plant Molluscicides (Eds.: B.O. Acosta \& K.E. Mott). John Wiley and Sons Ltd. Chichester. New York. Brisbane.Toronto. Singapore. p:45-108.

Lacanilao, F. (1990) reproduction of the golden apple snail, egg mass, haching, and incubation. Philipp. J. Sci. 119 (2):95-105.

Marston, A. \& K. Hostettmann (1985). Plant molluscicides. Phytochemistry. 24 (4):639-652.

Munandar, A. (2003). Serba-serbi Keong Murbei dan Keong Mas. Laporan tidak dipublikasikan. Balai Penelitian dan Pengembangan Zoologi. LIPI. Bogor.

Saxena, R.C., de Larsa, A.V. \& H.D. Husto (1987). Golden snail: A pest of rice. Int. Rice Newsl. 12 (1): 24-25

Sumangil, J.P. (1989). Biological control. In: Environmental Impact of The Golden Snail ( Pomacea sp.) on Rice Farming System in The Philippines ( Eds.: B.O. Acosta \& R.S.V.Pullin). International Center for Living Aquatic Resources Management. Manila p: 26-27.

Suripto, Jupri, H.A. \& G. Tresnani (2005). Spektrum efek toksik berbagai fraksi ekstrak daun jayanti terhadap keong mas dan tanaman padi, J. Biologi Tropis. 8:15-20.

Suripto, Gunawan, E.R., Tresnani, G. \& H.A. Jupri (2007). Pengembangan Kinerja Anti Moluska dari Tanaman Jayanti \{sesbania sesban (L.) Merr. untuk Mengendalikan Keong Mas Hama Tanaman Padi.. Laporan tidak dipublikasikan. Lembaga Penelitian Universitas Mataram.

Suripto, Gunawan, E.R., Tresnani, G. \& H.A. Jupri (2008). Pengembangan Kinerja Anti Moluska dari Tanaman Jayanti 
\{sesbania sesban (L.) Merr. untuk Mengendalikan Keong Mas Hama Tanaman Padi.. Laporan tidak dipublikasikan. Lembaga Penelitian Universitas Mataram. 